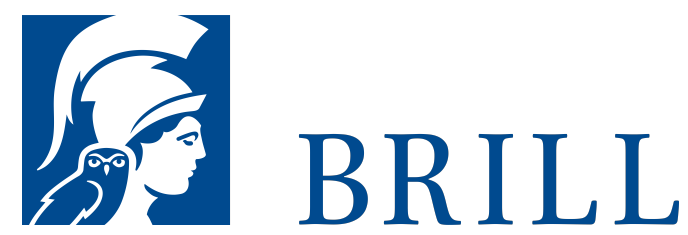

\section{Anspruchserfüllung und Portfolioauswahl}

Theoretische Diskussion und experimentelle Evidenz

Author: Werner Güth

Die Nordrhein-Westfälische Akademie der Wissenschaften und der Künste ist eine Vereinigung der führenden Forscherinnen und Forscher des Landes. Sie wurde 1970 als

Nachfolgeeinrichtung der Arbeitsgemeinschaft für Forschung des Landes Nordrhein-Westfalen gegründet. Die Akademie ist in drei wissenschaftliche Klassen für Geisteswissenschaften, für Naturwissenschaften und Medizin sowie für Ingenieur- und Wirtschaftswissenschaften und in eine Klasse der Künste gegliedert.

Mit Publikationen zu den wissenschaftlichen Vorträgen in den Klassensitzungen, zu öffentlichen Veranstaltungen und Symposien will die Akademie die Fach- und allgemeine Öffentlichkeit über die Arbeiten der Akademie und ihrer Forschungsstellen informieren.

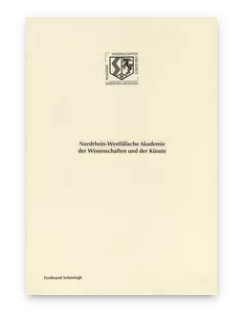

Pages: 29 Seiten

Language:

German

Subjects:

Economics \&

Political Science,

Social Sciences

Publisher: Brill |

Schöningh

Series:

Nordrhein Westfälische

Akademie der

Wissenschafte - Ingenieurund

Wirtschaftswissenschaften,

Volume: 19

E-Book (PDF)

Released online:

29Jan 2020

ISBN: $978-3^{-}$

657-76338-2

List price

USD $\$ 24.00$

Paperback

Publication date:

23 Jan 2007

ISBN: 978-3-

5०6-76338-9

List price

USD \$24.00 
For more information see brill.com

Order information: Order online at brill.com +44330 333 0049 | customerservices@brill.com Submission information: brill.com/authors

Titles published by Brill | Fink, Brill | mentis or Brill | Schöningh: +49(o)715413279216| brill@brocom.de 